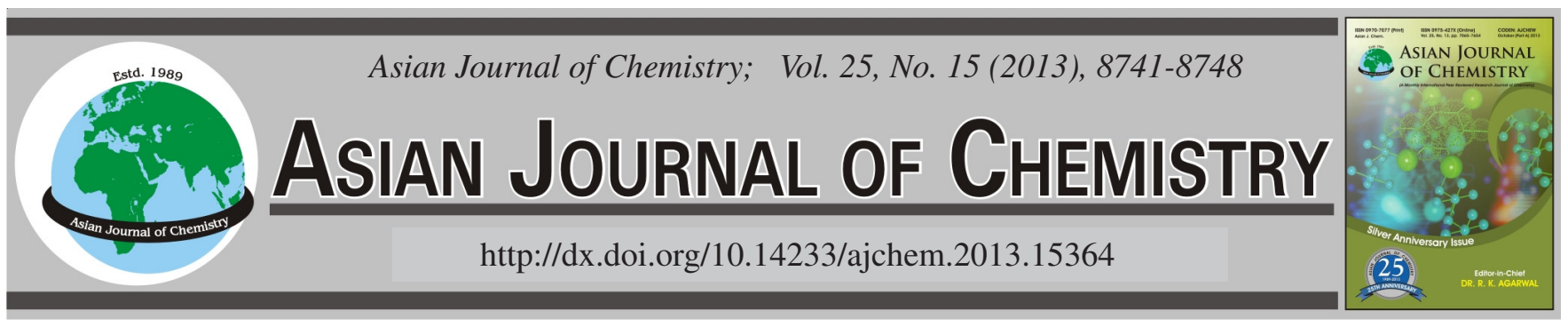

\title{
Facile Synthesis and Biological Evaluation of Substituted 5-(1H-Indol-3-ylmethylene) pyrimidine-2,4,6-trione Derivatives Using L-Tyrosine in Aqueous Medium
}

\author{
G. Thirupathi", P.K. Dubey and Y. Bharathi Kumari
}

Department of Chemistry, Jawaharlal Nehru Technological University Hyderabad, College of Engineering, Kukatpally, Hyderabad-500 085, India

*Corresponding author: E-mail: thirupathigjntuh@gmail.com

(Received: 20 February 2013;

Accepted: 29 August 2013)

AJC-14039

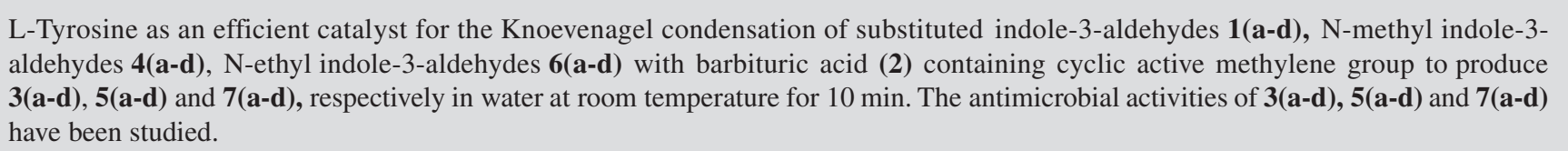

Key Words: Antibacterial activities, Antifungal activities, Indole-3-aldehyde, Barbituric acid, L-Tyrosine, Knoevenagel reaction.

\section{INTRODUCTION}

Carbon-carbon bond formation reaction is the most important reaction in organic synthesis ${ }^{1-4}$. The Knoevenagel condensation is one such reactions which facilitates C-C double bond formation and has been widely used in synthesis of alkenes of biological significance ${ }^{5-9}$. These reactions are usually catalyzed by bases ${ }^{10-17}$ such as ethylenediamine, potassium fluoroiodide, primary, secondary amines and their corresponding ammonium salts, Lewis acids ${ }^{18-20}$, zeolite $^{21-23}$ and ionic liquids ${ }^{24-27}$ have also been added to the existing list of substances that assisted Knoevenagel condensation in organic synthesis.

Knoevenagel condensation of meldrum's acid and aldehydes gives rise to substrates for variety of reactions ${ }^{28}$. They are used in cycloaddition reactions ${ }^{29}, 1,4$-conjugate addition reactions and preparation of mono alkyl meldrum's acid derivatives, preparation of deuterated carboxylic acid derivatives. These derivatives are also used in the preparation of ketenes by $\alpha, \beta$-pyrolysis, which are then used for preparation of different compounds such as cyclobutadiene derivatives ${ }^{30}, \alpha, \beta$ unsaturated esters ${ }^{31}$ and $\alpha, \beta$-unsaturated amides ${ }^{32-33}$.

Jones et al..$^{34}$ reported the reaction of meldrum's acid with indole-3-carboxaldehyde under flash-vacuum pyrolysis to yield the Knoevenagel derivative of 5-[(1H-indol-3-yl)methylene]2,2-dimethyl-1,3-dioxane-4,6-dione with $61 \%$ yield. This method is more time-consuming and not so good for the preparation of large amounts of these products. Moreover, it is a very good intermediate for the preparation of anticancer drug ${ }^{38}$.
L-Tyrosine is an known to be an efficient, bi-functional, zwitter ionic and eco-friendly catalyst. It is available in both the enantiomeric, (S)-tyrosine and (R)-tyrosine forms. The two functional groups of tyrosine enable it to act both as an acid as well as a base catalyst in chemical condensation reactions.

\section{EXPERIMENTAL}

Melting points were measured in open capillary tubes and are uncorrected. TLC was done on plates coated with silica gel-G and spotting was done using iodine or UV lamp. IR spectra were recorded using FT-IR in $\mathrm{KBr}$ phase. ${ }^{1} \mathrm{H}$ and ${ }^{13} \mathrm{C}$ NMR spectra were recorded at $400 \mathrm{MHz}$, respectively.

General procedure for the preparation of 3 from 1: A mixture of 1 (10 $\mathrm{mmol})$, barbituric acid acid 2 (10 $\mathrm{mmol})$ and L-tyrosine $(2 \mathrm{mmol})$ and water $(25 \mathrm{~mL})$ was stirred at room temperature for a specified period of time (Table-1). After completion of reaction (as shown by TLC checking), the mixture was poured into ice cold water $(50 \mathrm{~mL})$. The separated solid was filtered, washed with water $(100 \mathrm{~mL})$ and dried to obtain crude product 3 . The latter were then recrystallized from ethyl acetate to afford pure compound $\mathbf{3}$. Compounds are known and products were identified by spectral and meltingpoint comparison with the authentic samples.

General procedure for the preparation of 5 from 3: A mixture of compound 3 (10 mmol), DMS (10 mmol) and $\mathrm{Na}_{2} \mathrm{CO}_{3}$ was physical grinded in solvent free condition under grindstone method at room temperature for a specified period of time (Table-1). After completion of reaction (as shown by TLC checking), the mixture was poured into ice-cold water 
$(50 \mathrm{~mL})$. The separated solid was filtered, washed with water $(100 \mathrm{~mL})$ and dried to obtain crude $\mathbf{5}$. The latter were then recrystallised from ethyl acetate to afford pure 5. Compounds are known and products were identified by spectral and melting-point comparison with the authentic samples.

General procedure for the preparation of 7 from 3: A mixture of compound 3 (10 mmol), DES (10 mmol) and $\mathrm{Na}_{2} \mathrm{CO}_{3}$ was physical grinded in solvent free condition under grindstone method at room temperature for a specified period of time (Table-1). After completion of reaction (as shown by TLC checking), the mixture was poured into ice-cold water $(50 \mathrm{~mL})$. The separated solid was filtered, washed with water $(100 \mathrm{~mL})$ and dried to obtain crude compound 7 . The latter were then recrystallised from ethyl acetate to afford pure compound 7. Compounds are known and products were identified by spectral and melting-point comparison with the authentic samples.

5-(1H-Indol-3-ylmethylene)-pyrimidine-2,4,6-trione (3a): Yellow solid; yield $=2.448$ g $(96 \%)$; m.p. $251-253{ }^{\circ} \mathrm{C}$; IR (KBr, $\left.v_{\max }, \mathrm{cm}^{-1}\right): 3210$ (NH-indole), 3040 (aromatic C-H), $1685(\mathrm{C}=\mathrm{O}), 1674(\mathrm{~N}-\mathrm{CO}-\mathrm{N}) ; 1620(\mathrm{C}=\mathrm{C}) .{ }^{1} \mathrm{H}$ NMR (DMSO$\left.d_{6} / \mathrm{TMS}\right): \delta 7.31-7.62(\mathrm{~m}, 4 \mathrm{H}$, aryl protons of the indole ring), $7.84(\mathrm{~s}, 1 \mathrm{H}, \alpha$-proton of the indole ring), 8.32-8.45 (s, $1 \mathrm{H}$, vinylic proton of the indole ring), 9.85-9.96 (br, s, $1 \mathrm{H}, \mathrm{NH}$ proton of indole ring); 11.15-11 (brs, s, 2H, NH barbituric). ${ }^{13} \mathrm{C}$ spectrum (DMSO- $d_{6} / \mathrm{TMS}$ ): $\delta 113.01,117.74,122.6$, 123.6, 131.5, 140.4, 141.5, 144.95, $163.6(\mathrm{C}=\mathrm{O}), 171.31(\mathrm{~N}-$ CO-N); MS: $\mathrm{m} / \mathrm{z}=256.23(\mathrm{M}+1)$.

5-(5-Methoxy-1H-indol-3-ylmethylene)-pyrimidine2,4,6-trione (3b): Yellow solid; yield $=2.70 \mathrm{~g}(95 \%)$; m.p. 243-245 ${ }^{\circ} \mathrm{C}$; IR $\left(\mathrm{KBr}, v_{\max }, \mathrm{cm}^{-1}\right): 3210$ (NH-indole), 3040 (aromatic C-H), $1685(\mathrm{C}=\mathrm{O}), 1674(\mathrm{~N}-\mathrm{CO}-\mathrm{N}) ; 1620(\mathrm{C}=\mathrm{C})$. ${ }^{1} \mathrm{H}$ NMR (DMSO- $d_{6} / \mathrm{TMS}$ ): $\delta 3.83$ (s, 3H, $\mathrm{OCH}_{3}$ ), 7.31-7.62 $(\mathrm{m}, 4 \mathrm{H}$, aryl protons of the indole ring), $7.84(\mathrm{~s}, 1 \mathrm{H}, \alpha$-proton of the indole ring), 8.32-8.45 ( $\mathrm{s}, 1 \mathrm{H}$, vinylic proton of the indole ring), 9.85-9.96 (br, s, $1 \mathrm{H}, \mathrm{NH}$ proton of indole ring); 11.15-11.(brs, s, 2H, NH-barbituric). ${ }^{13} \mathrm{C}$ spectrum (DMSO$\left.d_{6} / \mathrm{TMS}\right): \delta 54.21,113.01,117.74,122.6,123.6,131.5,140.4$, $141.5,144.95,163.6(\mathrm{C}=\mathrm{O}), 171.31(\mathrm{~N}-\mathrm{CO}-\mathrm{N}) ; \mathrm{MS}: \mathrm{m} / \mathrm{z}=$ $286.25(\mathrm{M}+1)$.

5-(5-Bromo-1H-indol-3-ylmethylene)-pyrimidine2,4,6-trione (3c): Yellow solid; yield $=3.06 \mathrm{~g}(96 \%)$; m.p. 281-282 ${ }^{\circ} \mathrm{C}$; IR (KBr, $\left.v_{\max }, \mathrm{cm}^{-1}\right): 3210$ (NH-indole), 3040 (aromatic C-H), $1685(\mathrm{C}=\mathrm{O}), 1674(\mathrm{~N}-\mathrm{CO}-\mathrm{N}) ; 1620(\mathrm{C}=\mathrm{C})$. ${ }^{1} \mathrm{H}$ NMR (DMSO- $d_{6} / \mathrm{TMS}$ ): $\delta 7.31-7.62(\mathrm{~m}, 4 \mathrm{H}$, aryl protons of the indole ring), 7.84 (s, $1 \mathrm{H}, \alpha$-proton of the indole ring), 8.32-8.45 (s, $1 \mathrm{H}$, vinylic proton of the indole ring), 9.85-9.96 (br, s, 1H, NH proton of indole ring); 11.15-11 (brs, s, 2H, NH-barbituric). ${ }^{13} \mathrm{C}$ spectrum (DMSO- $d_{6} / \mathrm{TMS}$ ): $\delta 113.01$, 117.74, 122.6, 123.6, 131.5, 140.4, 141.5, 144.95, 163.6 $(\mathrm{C}=\mathrm{O}), 171.31(\mathrm{~N}-\mathrm{CO}-\mathrm{N}) ; \mathrm{MS}: \mathrm{m} / \mathrm{z}=320.11(\mathrm{M}+1)$.

5-(5-Nitro-1H-indol-3-ylmethylene)-pyrimidine-2,4,6trione (3d): Yellow solid; yield $=2.88 \mathrm{~g}(96 \%)$; m.p. 262$263{ }^{\circ} \mathrm{C}$; IR (KBr, $\left.v_{\max }, \mathrm{cm}^{-1}\right): 3210$ (NH-indole), 3040 (aromatic C-H), $1685(\mathrm{C}=\mathrm{O}), 1674(\mathrm{~N}-\mathrm{CO}-\mathrm{N}) ; 1620(\mathrm{C}=\mathrm{C}) .{ }^{1} \mathrm{H}$ NMR (DMSO- $\left.d_{6} / \mathrm{TMS}\right): \delta 7.31-7.62(\mathrm{~m}, 4 \mathrm{H}$, aryl protons of the indole ring), 7.84 (s, $1 \mathrm{H}, \alpha$-proton of the indole ring), 8.32$8.45(\mathrm{~s}, 1 \mathrm{H}$, vinylic proton of the indole ring), 9.85-9.96 (br, $\mathrm{s}, 1 \mathrm{H}, \mathrm{NH}$ proton of indole ring); 11.15-11 (brs, s, 2H, NHbarbituric). ${ }^{13} \mathrm{C}$ spectrum (DMSO- $d_{6} / \mathrm{TMS}$ ): $\delta 113.01,117.74$, 122.6, 123.6, 131.5, 140.4, 141.5, 144.95, 163.6 (C=O), 171.31 $(\mathrm{N}-\mathrm{CO}-\mathrm{N}) ; \mathrm{MS}: \mathrm{m} / \mathrm{z}=301.23(\mathrm{M}+1)$.

5-(1-Methyl-1H-indol-3-ylmethylene)-pyrimidine2,4,6-trione (5a): Yellow solid; yield $=2.52$ g (94\%); m.p. 247-249 ${ }^{\circ} \mathrm{C}$; IR (KBr, $\left.v_{\max }, \mathrm{cm}^{-1}\right): 3210$ (NH-indole), 3040 (aromatic C-H), $1685(\mathrm{C}=\mathrm{O}), 1674(\mathrm{~N}-\mathrm{CO}-\mathrm{N}) ; 1620(\mathrm{C}=\mathrm{C})$. ${ }^{1} \mathrm{H}$ NMR (DMSO- $d_{6} / \mathrm{TMS}$ ): $\delta 4.01$ (s, 3H, $\mathrm{N} \mathrm{CH}_{3}$ ), 7.31-7.62 $(\mathrm{m}, 4 \mathrm{H}$, aryl protons of the indole ring), 7.84 (s, $1 \mathrm{H}, \alpha$-proton of the indole ring), 8.32-8.45 (s, $1 \mathrm{H}$, vinylic proton of the indole ring), 9.85-9.96 (br, s, 1H, NH proton of indole ring); 11.15-11. (brs, s, $2 \mathrm{H}, \mathrm{NH}$-barbituric). ${ }^{13} \mathrm{C}$ spectrum (DMSO$\left.d_{6} / \mathrm{TMS}\right): \delta 34.02\left(\mathrm{~N}-\mathrm{CH}_{3}\right), 113.01,117.74,122.6,123.6$, 131.5, 140.4, 141.5, 144.95, $163.6(\mathrm{C}=\mathrm{O}), 171.31(\mathrm{~N}-\mathrm{CO}-\mathrm{N})$; MS: $\mathrm{m} / \mathrm{z}=270.26(\mathrm{M}+1)$.

5-(5-Methoxy-1-methyl-1H-indol-3-ylmethylene)pyrimidine-2,4,6-trione (5b): Yellow solid; yield $=2.78 \mathrm{~g}$ (93\%); m.p. $241-243{ }^{\circ} \mathrm{C}$; IR (KBr, $\left.v_{\max }, \mathrm{cm}^{-1}\right): 3210(\mathrm{NH}-$ indole), 3040 (aromatic C-H), $1685(\mathrm{C}=\mathrm{O}), 1674(\mathrm{~N}-\mathrm{CO}-\mathrm{N})$; $1620(\mathrm{C}=\mathrm{C}) .{ }^{1} \mathrm{H}$ NMR (DMSO- $\left.d_{6} / \mathrm{TMS}\right): \delta 4.01\left(\mathrm{~s}, 3 \mathrm{H}, \mathrm{N} \mathrm{CH}_{3}\right.$ ), $3.45\left(\mathrm{~s}, 3 \mathrm{H},-\mathrm{OCH}_{3}\right), 7.31-7.62(\mathrm{~m}, 4 \mathrm{H}$, aryl protons of the indole ring), 7.84 (s, $1 \mathrm{H}, \alpha$-proton of the indole ring), 8.328.45 (s, $1 \mathrm{H}$, vinylic proton of the indole ring), 9.85-9.96 (br, $\mathrm{s}, 1 \mathrm{H}, \mathrm{NH}$ proton of indole ring); $11.15-11$ (brs, s, 2H, NHbarbituric).${ }^{13} \mathrm{C}$ spectrum (DMSO- $\left.d_{6} / \mathrm{TMS}\right): \delta 34.02\left(\mathrm{~N}-\mathrm{CH}_{3}\right)$, 53.11, 113.01, 117.74, 122.6, 123.6, 131.5, 140.4, 141.5, 144.95, $163.6(\mathrm{C}=\mathrm{O}), 171.31(\mathrm{~N}-\mathrm{CO}-\mathrm{N}) ; \mathrm{MS}: \mathrm{m} / \mathrm{z}=300.28$ $(\mathrm{M}+1)$.

5-(5-Bromo-1-methyl-1H-indol-3-ylmethylene)-pyrimidine-2,4,6-trione (5c): Yellow solid; yield = 3.27 g (94\%); m.p. $265-266^{\circ} \mathrm{C}$; IR (KBr, $\left.v_{\max }, \mathrm{cm}^{-1}\right)$ : 3210 (NH-indole), 3040 (aromatic C-H), $1685(\mathrm{C}=\mathrm{O}), 1674(\mathrm{~N}-\mathrm{CO}-\mathrm{N}) ; 1620(\mathrm{C}=\mathrm{C})$. ${ }^{1} \mathrm{H}$ NMR (DMSO- $d_{6} / \mathrm{TMS}$ ): $\delta 4.01$ (s, 3H, $\mathrm{NCH}_{3}$ ), 7.31-7.62 $(\mathrm{m}, 4 \mathrm{H}$, aryl protons of the indole ring), $7.84(\mathrm{~s}, 1 \mathrm{H}, \alpha$-proton of the indole ring), 8.32-8.45 ( $\mathrm{s}, 1 \mathrm{H}$, vinylic proton of the indole ring), 9.85-9.96 (br, s, $1 \mathrm{H}, \mathrm{NH}$ proton of indole ring); 11.15-11. (brs, s, $2 \mathrm{H}, \mathrm{NH}$-barbituric). ${ }^{13} \mathrm{C}$ spectrum (DMSO$\left.d_{6} / \mathrm{TMS}\right): \delta 34.02\left(\mathrm{~N}-\mathrm{CH}_{3}\right), 113.01,117.74,122.6,123.6,131.5$, 140.4, 141.5, 144.95, $163.6(\mathrm{C}=\mathrm{O}), 171.31(\mathrm{~N}-\mathrm{CO}-\mathrm{N})$; MS: $\mathrm{m} / \mathrm{z}=349.15(\mathrm{M}+1)$.

5-(1-Methyl-5-nitro-1H-indol-3-ylmethylene)-pyrimidine-2,4,6-trione (5d): Yellow solid; yield $=2.95 \mathrm{~g}(94 \%)$; m.p. $254-257^{\circ} \mathrm{C}$; IR (KBr, $v_{\max }, \mathrm{cm}^{-1}$ ): 3210 (NH-indole), 3040 (aromatic C-H), $1685(\mathrm{C}=\mathrm{O}), 1674(\mathrm{~N}-\mathrm{CO}-\mathrm{N}) ; 1620(\mathrm{C}=\mathrm{C})$. ${ }^{1} \mathrm{H}$ NMR (DMSO- $d_{6} / \mathrm{TMS}$ ): $\delta 4.01$ (s, 3H, N CH $\mathrm{H}_{3}$ ), 7.31-7.62 ( $\mathrm{m}, 4 \mathrm{H}$, aryl protons of the indole ring), $7.84(\mathrm{~s}, 1 \mathrm{H}, \alpha$-proton of the indole ring), 8.32-8.45 ( $\mathrm{s}, 1 \mathrm{H}$, vinylic proton of the indole ring), 9.85-9.96 (br, s, $1 \mathrm{H}, \mathrm{NH}$ proton of indole ring); 11.15-11. (brs, s, 2H, NH-barbituric). ${ }^{13} \mathrm{C}$ spectrum (DMSO$\left.d_{6} / \mathrm{TMS}\right): \delta 34.02\left(\mathrm{~N}-\mathrm{CH}_{3}\right), 113.01,117.74,122.6,123.6,131.5$, 140.4, 141.5, 144.95, $163.6(\mathrm{C}=\mathrm{O}), 171.31(\mathrm{~N}-\mathrm{CO}-\mathrm{N})$; MS: $\mathrm{m} / \mathrm{z}=315.25(\mathrm{M}+1)$.

5-(1-Ethyl-1H-indol-3-ylmethylene)-pyrimidine-2,4,6trione (7a): Yellow solid; yield $=2.66 \mathrm{~g}$ (94\%); m.p. 243$245{ }^{\circ} \mathrm{C}$; IR (KBr, $\left.v_{\max }, \mathrm{cm}^{-1}\right): 3210$ (NH-indole), 3040 (aromatic C-H), $1685(\mathrm{C}=\mathrm{O}), 1674(\mathrm{~N}-\mathrm{CO}-\mathrm{N}) ; 1620(\mathrm{C}=\mathrm{C})$. ${ }^{1} \mathrm{H}$ NMR (DMSO- $d_{6} / \mathrm{TMS}$ ): $\delta 1.53$ (t, 3H, $\mathrm{CH}_{3}$ ), 4.03 (q, 2H, 
$\mathrm{CH}_{2}$ ), 7.31-7.62 (m, $4 \mathrm{H}$, aryl protons of the indole ring), 7.84 ( $\mathrm{s}, 1 \mathrm{H}, \alpha$-proton of the indole ring), 8.32-8.45 (s, $1 \mathrm{H}$, vinylic proton of the indole ring), 9.85-9.96 (br, s, 1H, NH proton of indole ring); $11.15-11$ (brs, s, $2 \mathrm{H}, \mathrm{NH}$-barbituric). ${ }^{13} \mathrm{C}$ spectrum (DMSO- $\left.d_{6} / \mathrm{TMS}\right): \delta 36.5,47.9,113.01,117.74,122.6,123.6$, $131.5,140.4,141.5,144.95,163.6(\mathrm{C}=\mathrm{O}), 171.31(\mathrm{~N}-\mathrm{CO}-\mathrm{N})$; MS: $\mathrm{m} / \mathrm{z}=284.28(\mathrm{M}+1)$.

5-(1-Ethyl-5-methoxy-1H-indol-3-ylmethylene)-pyrimidine-2,4,6-trione (7b): Yellow solid; yield $=2.91 \mathrm{~g}(93$ $\%$ ); m.p. $240-241{ }^{\circ} \mathrm{C}$; IR ( $\left.\mathrm{KBr}, \mathrm{v}_{\max }, \mathrm{cm}^{-1}\right): 3210$ (NH-indole), 3040 (aromatic C-H), $1685(\mathrm{C}=\mathrm{O}), 1674(\mathrm{~N}-\mathrm{CO}-\mathrm{N})$; $1620(\mathrm{C}=\mathrm{C}) .{ }^{1} \mathrm{H}$ NMR (DMSO- $\left.d_{6} / \mathrm{TMS}\right): \delta 1.54\left(\mathrm{t}, 3 \mathrm{H}, \mathrm{CH}_{3}\right)$, $3.62\left(\mathrm{~s}, 3 \mathrm{H}, \mathrm{OCH}_{3}\right), 4.15\left(\mathrm{q}, 2 \mathrm{H}, \mathrm{CH}_{2}\right), 7.31-7.62(\mathrm{~m}, 4 \mathrm{H}$, aryl protons of the indole ring), $7.84(\mathrm{~s}, 1 \mathrm{H}, \alpha$-proton of the indole ring), 8.32-8.45 ( $\mathrm{s}, 1 \mathrm{H}$, vinylic proton of the indole ring), 9.859.96 (br, s, 1H, NH proton of indole ring); 11.15-11 (brs, s, $2 \mathrm{H}$, NH-barbituric). ${ }^{13} \mathrm{C}$ spectrum (DMSO- $d_{6} / \mathrm{TMS}$ ): $\delta 36.5,47.9$, 56.5, 113.01, 117.74, 122.6, 123.6, 131.5, 140.4, 141.5, $144.95,163.6(\mathrm{C}=\mathrm{O}), 171.31(\mathrm{~N}-\mathrm{CO}-\mathrm{N}) ; \mathrm{MS}: \mathrm{m} / \mathrm{z}=314.31$ $(\mathrm{M}+1)$.

5-(5-Bromo-1-ethyl-1H-indol-3-ylmethylene)-pyrimidine-2,4,6-trione (7c): Yellow solid; yield $=3.40 \mathrm{~g}(94 \%)$; m.p. $261-262^{\circ} \mathrm{C}$; IR (KBr, $\left.v_{\max }, \mathrm{cm}^{-1}\right)$ : 3210 (NH-indole), 3040 (aromatic C-H), $1685(\mathrm{C}=\mathrm{O}), 1674(\mathrm{~N}-\mathrm{CO}-\mathrm{N}) ; 1620(\mathrm{C}=\mathrm{C})$. ${ }^{1} \mathrm{H}$ NMR (DMSO- $\left.d_{6} / \mathrm{TMS}\right): \delta 1.51\left(\mathrm{t}, 3 \mathrm{H}, \mathrm{CH}_{3}\right), 4.23(\mathrm{q}, 2 \mathrm{H}$, $\mathrm{CH}_{2}$ ), 7.31-7.62 ( $\mathrm{m}, 4 \mathrm{H}$, aryl protons of the indole ring), 7.84 (s, $1 \mathrm{H}, \alpha$-proton of the indole ring), 8.32-8.45 (s, $1 \mathrm{H}$, vinylic proton of the indole ring), 9.85-9.96 (br, s, 1H, NH proton of indole ring); $11.15-11$ (brs, s, $2 \mathrm{H}, \mathrm{NH}$-barbituric). ${ }^{13} \mathrm{C}$ spectrum (DMSO- $\left.d_{6} / \mathrm{TMS}\right): \delta 36.5,47.9,113.01,117.74,122.6,123.6$, 131.5, 140.4, 141.5, 144.95, $163.6(\mathrm{C}=\mathrm{O}), 171.31(\mathrm{~N}-\mathrm{CO}-\mathrm{N})$; MS: $\mathrm{m} / \mathrm{z}=363.18(\mathrm{M}+1)$.

5-(1-Ethyl-5-nitro-1H-indol-3-ylmethylene)-pyrimidine-2,4,6-trione (7d): Yellow solid; yield $=3.08 \mathrm{~g}(94 \%)$; m.p. $252-253^{\circ} \mathrm{C}$; IR ( $\mathrm{KBr}, \mathrm{v}_{\max }, \mathrm{cm}^{-1}$ ): 3210 (NH-indole), 3040 (aromatic C-H), $1685(\mathrm{C}=\mathrm{O}), 1674(\mathrm{~N}-\mathrm{CO}-\mathrm{N}) ; 1620(\mathrm{C}=\mathrm{C})$. ${ }^{1} \mathrm{H}$ NMR (DMSO- $d_{6} / \mathrm{TMS}$ ): $\delta 1.56$ (t, 3H, $\left.\mathrm{CH}_{3}\right), 4.65$ (q, 2H, $\left.\mathrm{N} \mathrm{CH}_{2}\right), 7.31-7.62(\mathrm{~m}, 4 \mathrm{H}$, aryl protons of the indole ring), $7.84(\mathrm{~s}, 1 \mathrm{H}, \alpha$-proton of the indole ring), 8.32-8.45 (s, $1 \mathrm{H}$, vinylic proton of the indole ring), 9.85-9.96 (br, s, $1 \mathrm{H}, \mathrm{NH}$ proton of indole ring); 11.15-11 (brs, s, 2H, NH-barbituric). ${ }^{13} \mathrm{C}$ spectrum (DMSO- $d_{6} / \mathrm{TMS}$ ): $\delta 36.5,47.9,113.01,117.74$, 122.6, 123.6, 131.5, 140.4, 141.5, 144.95, 163.6 (C=O), 171.31 $(\mathrm{N}-\mathrm{CO}-\mathrm{N}) ; \mathrm{MS}: \mathrm{m} / \mathrm{z}=329.28(\mathrm{M}+1)$.

\section{RESULTS AND DISCUSSION}

Treatment of substituted indole-3-carboxaldehydes 1(ad) and its $\mathrm{N}$-methyl derivative 4(a-d), $\mathrm{N}$-ethyl derivative 6(ad), each with barbituric acid containing cyclic active methylene group (2) in water at room temperature for $10 \mathrm{~min}$ resulted corresponding Knoevenagel products 3(a-d), 5(a-d) and 7(ad) in excellent yields (93-96 \%) (Scheme-I) (Table-1). LTyrosine as an eco-friendly and efficient catalyst to induce the reaction. Structures of all the products have been assigned based on spectral and analytical data.

In the absence of L-tyrosine, the reaction did not proceed even after refluxing the reactants in water for $20 \mathrm{~h}$. The use of L-tyrosine as a catalyst helps to complete the reaction in 10 min. Thus, L-tyrosine has been found to be efficient and eco-friendly catalyst for the Knoevenagel condensation reaction of indole-3-carboxyaldehyde (1) and its N-methyl derivative 4(a-d), N-ethyl derivative 6(a-d), each with barbituric acid containing cyclic active methylene group (2). The use of L-tyrosine as a catalyst helps to avoid the use of environmentally unfavourable organic solvents as reaction medium.

The above reactions of $\mathbf{1}(\mathbf{a}-\mathbf{d}), \mathbf{4}(\mathbf{a}-\mathbf{d})$ and $\mathbf{6}(\mathbf{a}-\mathbf{d})$ with barbituric acid were attempted in the presence of various amino acids like valine, glycine, alanine and Lysine but, there was not much progress in the reactions as seen by TLC examination of crude reaction mixtures. In the presence of phenyl alanine in water at room temperature, there was a little bit of progress, but the reaction was not completed for $16 \mathrm{~h}$.

The above reactions of substituted indole-3-aldehydes 1(a-d), 4(a-d) and 6(a-d) with barbituric acid containing cyclic active methylene group were attempted in the presence of L-proline and L-tryptophan low yields were obtained for $1 \mathrm{~h}$ in water at room temperature.

Treatment of substituted indole-3-carboxaldehydes 1(a-d) and its $\mathrm{N}$-methyl derivative 4(a-d), N-ethyl derivative 6(ad), each with barbituric acid containing cyclic active methylene group (2) were attempted in the presence of various bases like $\mathrm{NaOH}, \mathrm{KOH}$ were too strong bases to result in more by-products. Low yield was obtained and $5 \mathrm{~h}$ reaction time is needed using $\mathrm{K}_{2} \mathrm{CO}_{3}$, ammonium acetate, piperidine and triethylamine as catalyst for condensation of substituted indole-3-aldehydes 1(a-d), 4(a-d) and 6(a-d) with barbituric acids containing cyclic active methylene group (2) in water at room temperature.

Table-1 showed that the condensation of substituted indole-3-aldehydes $\mathbf{1}(\mathbf{a}-\mathbf{d}), \mathbf{4}(\mathbf{a}-\mathbf{d})$ and $\mathbf{6}(\mathbf{a}-\mathbf{d})$ with electron withdrawing group such as $-\mathrm{NO}_{2}$ and $-\mathrm{Br}$ at 5 th position with barbituric acid containing cyclic active methylene compounds can be carried out in relatively shorter time and higher yield than with electron donating group such as $-\mathrm{OCH}_{3}$ in water at room temperature.

This method was very facile and convenient for the preparation of large amounts of Knoevenagel adducts with high yields in less time. L-Tyrosine acted as base to induce the reaction. The use of L-tyrosine as a catalyst helps to avoid the use of environmentally unfavorable organic solvents (DMF, $\mathrm{C}_{6} \mathrm{H}_{6}, \mathrm{DMSO}, \mathrm{CHCl}_{3}, \mathrm{CH}_{3} \mathrm{CN}$, etc.) as the reaction medium. The L-tyrosine was readily reactive in water at room temperature compared to solvents such as methanol, ethanol, DMF, $\mathrm{C}_{6} \mathrm{H}_{6}$, etc.; that is why the yield was also very high when the reaction was carried out in water at room temperature.

In some cases, yields were very high when the nucleophile was very active such as 5-nitroindole-3-carboxaldehyde, $\mathrm{N}$-methyl-5-nitroindole-3-carboxa-ldehyde and N-ethyl-5nitroindole-3-carboxaldehyde.

However, 5-methoxy indole-3-carboxaldehyde, N-methyl5-methoxyindole-3-carboxy aldehyde, N-ethyl-5-methoxyindole-3-carboxaldehyde, 5-bromoindole-3-carboxaldehyde, $\mathrm{N}$-methyl-5-bromo indole-3-carboxy aldehyde, N-ethyl-5bromoindole-3-carboxaldehyde under went condensation very easily with barbituric acid in the presence of L-tyrosine in water at room temperature. 


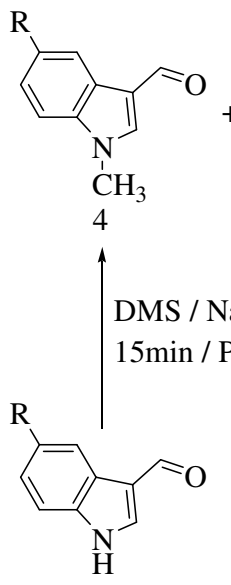<smiles>[R]c1ccc2c(c1)c(C=O)cn2CC</smiles>

6<smiles>O=C1CC(=O)NC(=O)N1</smiles>

2<smiles>[R]c1ccc2c(c1)c(C=C1C(=O)NC(=O)NC1=O)cn2C</smiles>

5 DMS / $\mathrm{Na}_{2} \mathrm{CO}_{3} /$ 20min / Physical grinding<smiles>[R]c1ccc2[nH]cc(C=C3C(=O)NC(=O)NC3=O)c2c1</smiles>

3

$\mathrm{DES} / \mathrm{Na}_{2} \mathrm{CO}_{3} /$ $20 \mathrm{~min} /$ Physical grinding

$5 \mathrm{~min} /$ Physical grinding<smiles>COC(=O)NC(=O)CC(=O)NC(=O)CS</smiles><smiles>[R]c1ccc2c(c1)c(C=C1C(=O)NC(=O)NC1=O)cn2CC</smiles>

7

\footnotetext{
$\mathrm{R}=\mathrm{H}, \mathrm{NO}_{2}, \mathrm{Br}, \mathrm{OCH}_{3}$
}

Scheme-I: Knoevenagel condensation of indole-3-aldehyde with barbituric acid in presense of L-tyrosine in water at room temperature

\begin{tabular}{|c|c|c|c|c|c|c|}
\hline \multicolumn{7}{|c|}{$\begin{array}{l}\text { TABLE-1 } \\
\text { SYNTHESIS OF NOVEL KNOEVENAGEL PRODUCTS BY USING L-TYROSINE } \\
\text { AS ECO-FRIENDLY CATALYST IN WATER AT ROOM TEMPERATURE }\end{array}$} \\
\hline S. No. & \multicolumn{2}{|c|}{ Reactants } & Product & Time (min) & Yield (\%) & m.p. $\left({ }^{\circ} \mathrm{C}\right)$ \\
\hline 1 & $1 \mathbf{a}(\mathrm{R}=\mathrm{H})$ & 2 & 3a $(\mathrm{R}=\mathrm{H})$ & 10 & 96 & $251-253$ \\
\hline 2 & $\mathbf{1 b}(\mathrm{R}=\mathrm{OMe}$ & 2 & $\mathbf{3 b}(\mathrm{R}=\mathrm{OMe}$ & 12 & 95 & $243-245$ \\
\hline 3 & $1 \mathrm{c}(\mathrm{R}=\mathrm{Br})$ & 2 & $3 c(\mathrm{R}=\mathrm{Br})$ & 9 & 96 & $281-282$ \\
\hline 4 & $1 d\left(\mathrm{R}=\mathrm{NO}_{2}\right)$ & 2 & $3 d\left(\mathrm{R}=\mathrm{NO}_{2}\right)$ & 9 & 96 & $262-264$ \\
\hline 5 & $4 a(R=H)$ & 2 & $5 \mathbf{a}(\mathrm{R}=\mathrm{H})$ & 11 & 94 & $247-249$ \\
\hline 6 & $\mathbf{4 b}(\mathrm{R}=\mathrm{OMe}$ & 2 & $\mathbf{5 b}(\mathrm{R}=\mathrm{OMe}$ & 14 & 93 & $240-243$ \\
\hline 7 & $4 c(\mathrm{R}=\mathrm{Br})$ & 2 & $\mathbf{5 c}(\mathrm{R}=\mathrm{Br})$ & 13 & 94 & $265-266$ \\
\hline 8 & $4 d\left(\mathrm{R}=\mathrm{NO}_{2}\right)$ & 2 & $5 d\left(\mathrm{R}=\mathrm{NO}_{2}\right)$ & 13 & 94 & $254-257$ \\
\hline 9 & $\mathbf{6 a}(\mathrm{R}=\mathrm{H})$ & 2 & $7 \mathbf{a}(\mathrm{R}=\mathrm{H})$ & 11 & 94 & $243-245$ \\
\hline 10 & $\mathbf{6 b}(\mathrm{R}=\mathrm{OMe}$ & 2 & $7 \mathbf{b}(\mathrm{R}=\mathrm{OMe}$ & 14 & 93 & $240-242$ \\
\hline 11 & $\mathbf{6 c}(\mathrm{R}=\mathrm{Br})$ & 2 & 7c $(\mathrm{R}=\mathrm{Br})$ & 13 & 94 & $261-262$ \\
\hline 12 & $\mathbf{6 d}\left(\mathrm{R}=\mathrm{NO}_{2}\right)$ & 2 & $7 d\left(\mathrm{R}=\mathrm{NO}_{2}\right)$ & 13 & 94 & $252-253$ \\
\hline 13 & 3a $(\mathrm{R}=\mathrm{H})$ & DMS & 5a $(\mathrm{R}=\mathrm{H})$ & 20 & 94 & $247-249$ \\
\hline 14 & $\mathbf{3 b}(\mathrm{R}=\mathrm{OMe}$ & DMS & $5 \mathbf{b}(\mathrm{R}=\mathrm{OMe}$ & 23 & 93 & $240-243$ \\
\hline 15 & $\mathbf{3 c}(\mathrm{R}=\mathrm{Br})$ & DMS & $\mathbf{5 c}(\mathrm{R}=\mathrm{Br})$ & 21 & 94 & $265-266$ \\
\hline 16 & $\mathbf{3 d}\left(\mathrm{R}=\mathrm{NO}_{2}\right)$ & DMS & $\mathbf{5 d}\left(\mathrm{R}=\mathrm{NO}_{2}\right)$ & 20 & 94 & $254-257$ \\
\hline 17 & $\mathbf{3 a}(\mathrm{R}=\mathrm{H})$ & DES & $7 \mathbf{a}(\mathrm{R}=\mathrm{H})$ & 20 & 94 & $243-245$ \\
\hline 18 & $\mathbf{3 b}(\mathrm{R}=\mathrm{OMe}$ & DES & $7 \mathbf{b}(\mathrm{R}=\mathrm{OMe}$ & 23 & 93 & $240-242$ \\
\hline 19 & 3c $(\mathrm{R}=\mathrm{Br})$ & DES & $7 \mathbf{c}(\mathrm{R}=\mathrm{Br})$ & 21 & 94 & $261-262$ \\
\hline 20 & $3 \mathbf{d}\left(\mathrm{R}=\mathrm{NO}_{2}\right)$ & DES & $7 \mathbf{d}\left(\mathrm{R}=\mathrm{NO}_{2}\right)$ & 20 & 94 & $252-253$ \\
\hline
\end{tabular}

Treatment of 3(a-d) independently with DMS and DES each, in the presence of $\mathrm{Na}_{2} \mathrm{CO}_{3}$ as base in solvent free condition under grindstone method at room temperature for $1 \mathrm{~h}$ resulted corresponding $\mathbf{5}(\mathbf{a}-\mathbf{d})$ and $\mathbf{7}(\mathbf{a}-\mathbf{d})$, respectively in excellent yields 93-94\% (Scheme-I). The compounds 5(a-d) and 7(a-d) could also be synthesized in an alternative manner. The compounds 4(a-d) and 6(a-d) were obtained from 1(a- d) by alkylation with DMS and DES each, in the presence of $\mathrm{Na}_{2} \mathrm{CO}_{3}$ as base in solvent free condition under grindstone method at room temperature.

A comparative study of the progress of condensation reactions $\mathbf{1}(\mathbf{a}-\mathbf{d}), \mathbf{4}(\mathbf{a}-\mathbf{d})$ and $\mathbf{6}(\mathbf{a}-\mathbf{d})$ with $\mathbf{2}$ were carried out in different solvents contaning along with L-tyrosine as catalyst and is summarized in Table-2. 
TABLE-2

PROGRESS OF REACTION IN DIFFERENT SOLVENT MEDIA

\begin{tabular}{ccccc}
\hline Entry & Solvent & $\begin{array}{c}\text { Time } \\
(\mathrm{h})\end{array}$ & Temp. $\left({ }^{\circ} \mathrm{C}\right)$ & $\begin{array}{c}\text { Yield } \\
(\%)\end{array}$ \\
\hline 1 & L-Tyrosine/water & 1 & r.t. & $93-96$ \\
2 & L-Tyrosine/EtOH & $2-5$ & r.t. & $72-76$ \\
3 & L-Tyrosine/benzene & 8 & r.t. & $44-46$ \\
4 & L-Tyrosine/DMSO & 10 & r.t. & $38-40$ \\
5 & Without catalyst in water & 24 & r.t./reflux at & Nil \\
& & & 100 & \\
6 & L-Tyrosine/DMF & 7 & r.t. & $28-30$ \\
7 & L-Tyrosine/CH $\mathrm{CN}_{3}$ & 12 & r.t. & $19-21$ \\
8 & L-Tyrosine/ $/ \mathrm{CHCl}_{3}$ & 18 & r.t. & Nil \\
\hline
\end{tabular}

A plausible mechanism for the formation of $\mathbf{3}$ from $\mathbf{1}$ and 2 in the presence of L-tyrosine as catalyst is shown in the Scheme-II. The reaction mechanism is supported by literature reference.

In the mechanism shown in Scheme-II, L-tyrosine, in its zwitter ionic form (Xb), abstracts a proton from barbituric acid containing cyclic active methylene group (2) forming the carbanion of barbituric acid $\left(2^{\mathrm{I}}\right)$ which then attacks the protonated indole-3-aldehydes $\left(\mathbf{1}^{\mathrm{I}}\right)$ forming the corresponding intermediate $\left(\mathbf{1}^{\mathrm{II}}\right)$ that loses water to form the end product 3.

\section{Biological evaluation}

Antibacterial activity: All the compounds substituted-5(1H-Indol-3-ylmethylene)-pyrimidine-2,4,6-trione, $\mathrm{N}$ alkyl derivatives 3(a-d), 5(a-d) and 7(a-d) were screened for their antibacterial activities ${ }^{35}$ against gram positive bacteria such as Bacillus subtilis, Staphylo coccusaureus (ATCC6538) and also against gram-negative bacteria such as Klebsiella pneumonia, Escherichia coli (ATCC8739) bacterial strains ${ }^{36}$ at concentrations of 50, 100, 200, 300 and $500 \mu \mathrm{g} / \mathrm{mL}$. Streptomycin was used as a reference standard. Petri plates and necessary glassware were sterilized in hot air oven at $190{ }^{\circ} \mathrm{C}$ for $45 \mathrm{~min}$. The Mueller Hinton Agar and saline $(0.82 \% \mathrm{NaCl})$ media were sterilized in autoclave $\left(121^{\circ} \mathrm{C}, 15 \mathrm{psi}, 20 \mathrm{~min}\right)$. Inoculum was prepared in sterile saline $(0.82 \% \mathrm{NaCl})$ and the optical density of all pathogens was adjusted to 0.10 at $625 \mathrm{~nm}$ on a chemito spectra scan UV 2600 spectrophotometer that is equivalent to $0.5 \mathrm{Mc}$ Farland standards. The Mueller Hinton Agar plates were prepared by the pour plate method. The activity of the compounds was tested by agar well diffusion method. All the bacterial cells were cultured in Mueller Hinton Agar plates and the compounds to be tested were dissolved in N,N-dimethyl formamide and were soaked in agar well and the Petri plates incubated at $37^{\circ} \mathrm{C}$ for $24 \mathrm{~h}$. The diameter $(\mathrm{mm})$ of the zone of inhibition around each agar disc was measured and results were recorded in Table-3. 3(ad), 5(a-d) and 7(a-d) compounds tested were found to have excellent antibacterial activity against Klebsiella pneumoniae and Escherichia coli. However, they were found to have very good activity against Staphylococcus aureus and Bacillus subtilis. 3(a-d) compounds tested were found to have more antibacterial activities compare with 5(a-d) and 7(a-d) against Klebsiella pneumoniae, Escherichia coli, Staphylococcus aureus and Bacillus subtilis.

Antifungal activity: All the compounds 3(a-d), 5(a-d) and 7(a-d) were screened for antifungal activity agains $\mathrm{t}^{37,38}$ Rhizoctonia solani, Fusarium oxysporum, Aspergillus niger and Aspergillus flavus at concentrations of 50, 100, 200, 300 and $500 \mu \mathrm{g} / \mathrm{mL}$. Mycostatin was used as a reference standard. Potato dextrose agar (PDA) was used as basal medium for test fungi. Glass petridishes used were sterilized. Sterilized melted PDA medium $\left(c a .45^{\circ} \mathrm{C}\right.$ ) was poured at the rate of $15 \mathrm{~mL}$ into each petridish $(90 \mathrm{~mm})$. After solidification of the medium, small portions of the mycelium of each fungus were spread carefully over the centre of each PDA plate with the help of

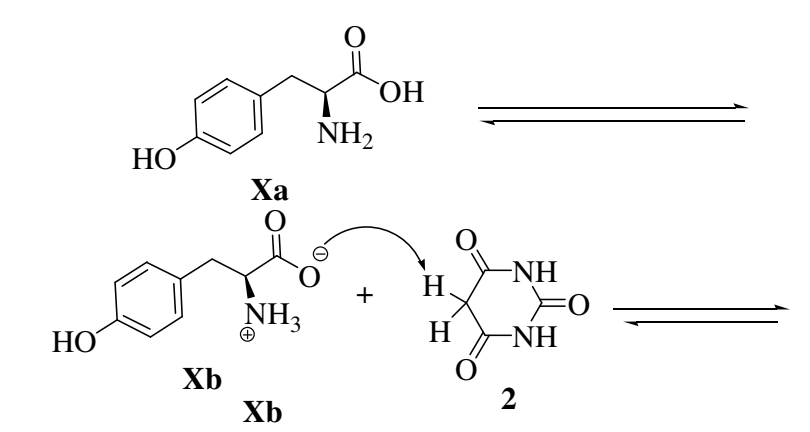<smiles>NC(Cc1ccc(O)cc1)C(=O)[O-]</smiles><smiles>[X]C(Cc1ccc(O)cc1)C(=O)O[CH+]C1C(=O)NC(=O)NC1=O</smiles><smiles>[X][M]N[C@@H](Cc1ccc(O)cc1)C(=O)O</smiles><smiles>[R]c1ccc2[nH]cc(/C=C/[OH2+])c2c1</smiles>

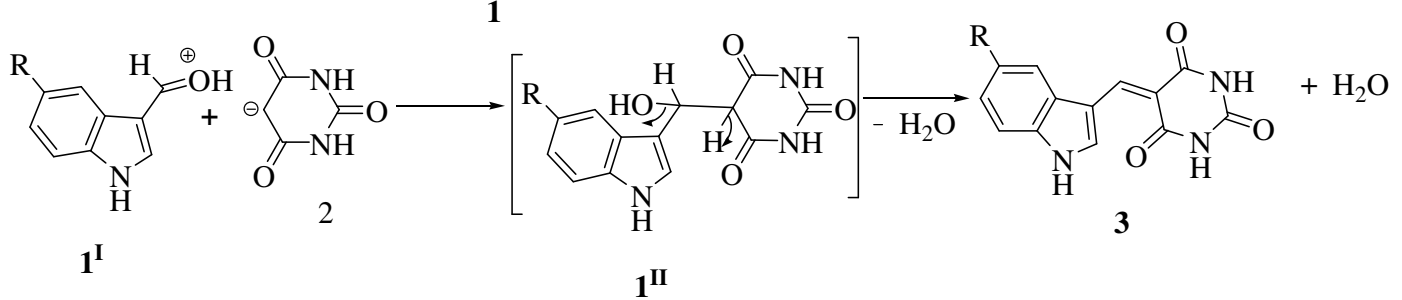

Scheme-II: Plausible mechanism for the formation of $\mathbf{3}$ from $\mathbf{1}$ and $\mathbf{2}$ in the presence of L-tyrosine in water at room temperature 
TABLE-3

ANTIBACTERIAL ACTIVITY OF 3(a-d), 5(a-d) AND 7(a-d) AGAINST

Klebsiella pneumonia, Escherichia Coli, Staphylococcus aureus AND Bacillus subtilis

\begin{tabular}{|c|c|c|c|c|c|c|c|}
\hline \multirow{2}{*}{ S. No. } & \multirow{2}{*}{$\begin{array}{c}\text { Compound } \\
\text { No. }\end{array}$} & \multirow{2}{*}{ Types of bacteria } & \multicolumn{5}{|c|}{ Zone of inhibition in $\mathrm{mm}$ for concentration of } \\
\hline & & & $50(\mu \mathrm{g} / \mathrm{mL})$ & $100(\mu \mathrm{g} / \mathrm{mL})$ & $200(\mu \mathrm{g} / \mathrm{mL})$ & $300(\mu \mathrm{g} / \mathrm{mL})$ & $500(\mu \mathrm{g} / \mathrm{mL})$ \\
\hline \multirow{4}{*}{1} & \multirow{4}{*}{$3 \mathbf{a}$} & Klebsiella pneumonia & 9 & 14 & 18 & 23 & 31 \\
\hline & & Escherichia coli & 8 & 13 & 16 & 20 & 30 \\
\hline & & Staphylococcus aureus & 6 & 10 & 14 & 18 & 25 \\
\hline & & Bacillus subtilis & 4 & 9 & 12 & 15 & 23 \\
\hline \multirow{4}{*}{2} & \multirow{4}{*}{$\mathbf{3 b}$} & Klebsiella pneumonia & 9 & 14 & 18 & 23 & 32 \\
\hline & & Escherichia coli & 8 & 13 & 15 & 20 & 31 \\
\hline & & Staphylococcus aureus & 6 & 10 & 13 & 16 & 26 \\
\hline & & Bacillus subtilis & 4 & 9 & 11 & 14 & 22 \\
\hline \multirow{4}{*}{3} & \multirow{4}{*}{$3 c$} & Klebsiella pneumonia & 9 & 14 & 18 & 23 & 32 \\
\hline & & Escherichia coli & 8.4 & 13.5 & 14 & 21 & 30 \\
\hline & & Staphylococcus aureus & 6 & 10 & 13 & 17 & 25 \\
\hline & & Bacillus subtilis & 5 & 9.5 & 11 & 15 & 23 \\
\hline \multirow{3}{*}{4} & \multirow{3}{*}{ 3d } & Klebsiella pneumonia & 9 & 14 & 18 & 23 & 32 \\
\hline & & Staphylococcus aureus & 6 & 10 & 13 & 16 & 26 \\
\hline & & Bacillus subtilis & 4 & 9 & 11 & 14 & 22 \\
\hline \multirow{4}{*}{5} & \multirow{4}{*}{$5 \mathbf{a}$} & Klebsiella pneumonia & 9 & 14 & 18 & 23 & 31 \\
\hline & & Escherichia coli & 8 & 13 & 16 & 20 & 30 \\
\hline & & Staphylococcus aureus & 6 & 10 & 14 & 18 & 25 \\
\hline & & Bacillus subtilis & 4 & 9 & 12 & 15 & 23 \\
\hline \multirow{4}{*}{6} & \multirow{4}{*}{$5 \mathbf{b}$} & Klebsiella pneumonia & 9 & 14 & 18 & 23 & 32 \\
\hline & & Escherichia coli & 8 & 13 & 15 & 20 & 31 \\
\hline & & Staphylococcus aureus & 6 & 10 & 13 & 16 & 26 \\
\hline & & Bacillus subtilis & 4 & 9 & 11 & 14 & 22 \\
\hline \multirow{4}{*}{7} & \multirow{4}{*}{$5 \mathbf{c}$} & Klebsiella pneumonia & 9 & 14 & 18 & 23 & 32 \\
\hline & & Escherichia coli & 8.4 & 13.5 & 14 & 21 & 30 \\
\hline & & Staphylococcus aureus & 6 & 10 & 13 & 17 & 25 \\
\hline & & Bacillus subtilis & 5 & 9.5 & 11 & 15 & 23 \\
\hline & & Klebsiella pneumonia & 9 & 14 & 18 & 23 & 31 \\
\hline & & Bacillus subtilis & 4 & 9 & 12 & 15 & 23 \\
\hline & & Klebsiella pneumonia & 9 & 14 & 18 & 23 & 31 \\
\hline 0 & & Escherichia coli & 8 & 13 & 16 & 20 & 30 \\
\hline 9 & $7 \mathbf{a}$ & Staphylococcus aureus & 6 & 10 & 14 & 18 & 25 \\
\hline & & Bacillus subtilis & 4 & 9 & 11 & 14 & 22 \\
\hline & & Klebsiella pneumonia & 8 & 13 & 15 & 20 & 31 \\
\hline 10 & $7 \mathbf{h}$ & Escherichia coli & 6 & 10 & 13 & 16 & 26 \\
\hline 10 & $/ \mathrm{D}$ & Staphylococcus aureus & 4 & 9 & 11 & 14 & 22 \\
\hline & & Bacillus subtilis & 4 & 8 & 10 & 13 & 21 \\
\hline & & Klebsiella pneumonia & 8.4 & 13.4 & 14 & 21 & 30 \\
\hline 11 & $7 \mathrm{~s}$ & Escherichia coli & 6 & 10 & 13 & 17 & 25 \\
\hline 11 & /e & Staphylococcus aureus & 5 & 9.5 & 11 & 15 & 23 \\
\hline & & Bacillus subtilis & 5 & 9.5 & 11 & 15 & 23 \\
\hline & & Klebsiella pneumonia & 9 & 14 & 18 & 23 & 32 \\
\hline 12 & $7 d$ & Escherichia coli & 8 & 13 & 15 & 20 & 31 \\
\hline 12 & $/ \mathbf{a}$ & Staphylococcus aureus & 6 & 10 & 13 & 16 & 26 \\
\hline & & Bacillus subtilis & 4 & 9 & 11 & 14 & 22 \\
\hline & & Klebsiella pneumonia & 11 & 16 & 22 & 26 & 35 \\
\hline 13 & Strentomycin & Escherichia coli & 10 & 15 & 21 & 24 & 34 \\
\hline 15 & streptomycin & Staphylococcus aureus & 8 & 13 & 17 & 20 & 29 \\
\hline & & Bacillus subtilis & 7 & 12 & 15 & 18 & 26 \\
\hline
\end{tabular}

sterilized needles. Thus, each fungus was transferred to a number of PDA plates, which were then incubated at $(25 \pm 2)$ ${ }^{\circ} \mathrm{C}$ and ready for use after 5 days of incubation agar plates were prepared by the pour plate method. The activity of the compounds was tested by agar well diffusion method, freshly seeded with the test organisms with sterile forceps. A control agar well was also prepared on the test plates to compare the effect of the test samples and to nullify the effect of solvent, respectively. The plates were then kept in a refrigerator at $4{ }^{\circ} \mathrm{C}$ for $24 \mathrm{~h}$ so that the materials had sufficient time to diffuse over a considerable area of the plates. After this, the plates were incubated at $37{ }^{\circ} \mathrm{C}$ for $72 \mathrm{~h}$. N,N-Dimethyl formamide was used as solvent to prepare desired solutions of the compounds and also to maintain proper control. The diameter 


\begin{tabular}{|c|c|c|c|c|c|c|c|}
\hline \multicolumn{8}{|c|}{$\begin{array}{c}\text { TABLE-4 } \\
\text { ANTIFUNGAL ACTIVITY OF 3(a-d), 5(a-d) AND 7(a-d) AGAINST } \\
\text { Rhizoctonia solani, Fusarium oxysporum, Aspergillus niger AND Aspergillus flavus }\end{array}$} \\
\hline \multirow{2}{*}{ S. No. } & \multirow{2}{*}{$\begin{array}{l}\text { Compound } \\
\text { No. }\end{array}$} & \multirow{2}{*}{ Types of bacteria } & \multicolumn{5}{|c|}{ Zone of inhibition in $\mathrm{mm}$ for concentration of } \\
\hline & & & $50(\mu \mathrm{g} / \mathrm{mL})$ & $100(\mu \mathrm{g} / \mathrm{mL})$ & $200(\mu \mathrm{g} / \mathrm{mL})$ & $300(\mu \mathrm{g} / \mathrm{mL})$ & $500(\mu \mathrm{g} / \mathrm{mL})$ \\
\hline \multirow{4}{*}{1} & \multirow{4}{*}{$\mathbf{3 a}$} & Rhizoctonia solani & 9 & 14 & 18 & 23 & 31 \\
\hline & & Fusarium oxysporum & 9 & 13.8 & 17 & 22.6 & 30 \\
\hline & & Aspergillus niger & 6 & 10 & 14 & 18 & 25 \\
\hline & & Aspergillus flavus & 6.5 & 11 & 13.6 & 18.3 & 25.2 \\
\hline \multirow{4}{*}{2} & \multirow{4}{*}{$\mathbf{3 b}$} & Rhizoctonia solani & 8 & 13 & 15 & 20 & 31 \\
\hline & & Fusarium oxysporum & 8 & 13 & 14 & 19 & 30 \\
\hline & & Aspergillus niger & 4 & 9 & 11 & 14 & 22 \\
\hline & & Aspergillus flavus & 4.3 & 8.9 & 11.1 & 13.9 & 22.1 \\
\hline \multirow{4}{*}{3} & \multirow{4}{*}{$3 c$} & Rhizoctonia solani & 8.4 & 13.5 & 14 & 21 & 30 \\
\hline & & Fusarium oxysporum & 8 & 13 & 13 & 20 & 29 \\
\hline & & Aspergillus niger & 5 & 9.5 & 11 & 15 & 23 \\
\hline & & Aspergillus flavus & 5 & 9 & 10.8 & 14.8 & 23 \\
\hline \multirow{4}{*}{4} & \multirow{4}{*}{ 3d } & Rhizoctonia solani & 9 & 14 & 18 & 23 & 32 \\
\hline & & Fusarium oxysporum & 8 & 13 & 15 & 20 & 31 \\
\hline & & Aspergillus niger & 6 & 10 & 12 & 15 & 23 \\
\hline & & Aspergillus flavus & 4 & 9 & 11 & 14 & 22 \\
\hline \multirow{4}{*}{5} & \multirow{4}{*}{$5 a$} & Rhizoctonia solani & 9 & 14 & 18 & 23 & 31 \\
\hline & & Fusarium oxysporum & 8 & 13 & 16 & 20 & 30 \\
\hline & & Aspergillus niger & 6 & 10 & 14 & 18 & 25 \\
\hline & & Aspergillus flavus & 4 & 9 & 12 & 15 & 23 \\
\hline \multirow{4}{*}{6} & \multirow{4}{*}{$5 b$} & Rhizoctonia solani & 9 & 14 & 18 & 23 & 32 \\
\hline & & Fusarium oxysporum & 8 & 13 & 15 & 20 & 31 \\
\hline & & Aspergillus niger & 6 & 10 & 13 & 16 & 26 \\
\hline & & Aspergillus flavus & 4 & 9 & 11 & 14 & 22 \\
\hline \multirow{4}{*}{7} & & Rhizoctonia solani & 9 & 14 & 18 & 23 & 32 \\
\hline & & Fusarium oxysporum & 8.4 & 13.5 & 14 & 21 & 30 \\
\hline & $5 c$ & Aspergillus niger & 6 & 10 & 13 & 17 & 25 \\
\hline & & Aspergillus flavus & 5 & 9.5 & 11 & 15 & 23 \\
\hline & & Rhizoctonia solani & 9 & 14 & 18 & 23 & 32 \\
\hline & & Fusarium oxysporum & 8 & 13 & 15 & 20 & 31 \\
\hline 8 & $5 d$ & Aspergillus niger & 6 & 10 & 13 & 16 & 26 \\
\hline & & Aspergillus flavus & 4 & 9 & 11 & 14 & 22 \\
\hline & & Rhizoctonia solani & 9 & 14 & 18 & 23 & 31 \\
\hline & & Fusarium oxysporum & 9 & 14 & 17 & 22 & 30 \\
\hline 9 & $7 \mathbf{a}$ & Aspergillus niger & 5 & 9 & 12 & 15 & 23 \\
\hline & & Aspergillus flavus & 4.8 & 8.7 & 11.8 & 14.6 & 23 \\
\hline & & Rhizoctonia solani & 9 & 14 & 18 & 23 & 32 \\
\hline & & Fusarium oxysporum & 9 & 13.9 & 18 & 22.7 & 31.8 \\
\hline 10 & $7 b$ & Aspergillus niger & 6 & 10 & 12 & 15 & 23 \\
\hline & & Aspergillus flavus & 5.4 & 9.7 & 11 & 14.6 & 22 \\
\hline & & Rhizoctonia solani & 9 & 14 & 18 & 23 & 32 \\
\hline & & Fusarium oxysporum & 8.4 & 13.5 & 17 & 22 & 31 \\
\hline 11 & $7 \mathrm{c}$ & Aspergillus niger & 5.3 & 10 & 11 & 15 & 24 \\
\hline & & Aspergillus flavus & 5 & 9.5 & 11 & 14.7 & 23 \\
\hline & & Rhizoctonia solani & 8 & 13 & 17 & 22 & 30 \\
\hline & & Fusarium oxysporum & 8 & 12 & 16 & 21 & 29 \\
\hline 12 & 7d & Aspergillus niger & 4 & 8 & 11.2 & 14.3 & 22 \\
\hline & & Aspergillus flavus & 4 & 8 & 11 & 14 & 22 \\
\hline & & Rhizoctonia solani & 13 & 16 & 20 & 28 & 35 \\
\hline & & Fusarium oxysporum & 13 & 16 & 19 & 27 & 35 \\
\hline 13 & Mycostanin & Aspergillus niger & 9.2 & 11 & 14.6 & 21 & 30 \\
\hline & & Aspergillus flavus & 9 & 11 & 14 & 20 & 29 \\
\hline
\end{tabular}

$(\mathrm{mm})$ of the zone of inhibition around each agar well was measured and results were recorded in Table-4.

3(a-d), 5(a-d) and 7(a-d) compounds tested were found to have very good antifungal activity against Rhizoctonia solani and Fusarium oxysporum. However, they were found to good activity against Aspergillus niger and Aspergillus flavus.

3(a-d) compounds tested were found to have more antifungal activities compare with $\mathbf{5}(\mathbf{a}-\mathbf{d})$ and $\mathbf{7}(\mathbf{a}-\mathbf{d})$ against
Rhizoctonia solani, Fusarium oxysporum, Aspergillus niger and Aspergillus flavus.

\section{Conclusion}

In summary, L-tyrosine has been employed as efficient, eco-friendly catalyst for the preparation of substituted-5-(1HIndol-3-ylmethylene)-pyrimidine-2,4,6 trione derivatives by Knoevenagel reaction in water at room temperature. This 
method is applicable to a wide range of indole-3-carboxyldehydes, including N-substituted indole-3-carboxyaldehydes. The attractive features of this procedure are the mild reaction conditions, high conversions, operational simplicity and inexpensive and ready availability of the catalyst, all of which make it a useful and attractive strategy for the preparation of substituted-5-(1H-indol-3-ylmethylene)-pyrimidine-2,4,6trione derivatives in water at room temperature. The antibacterial and antifungal activities of 3(a-d), 5(a-d) and 7(a-d) have been studied. 3(a-d), 5(a-d) and 7(a-d) compounds tested were found to have excelent antibacterial activities against Klebsiella pneumoniae and Escherichia coli. 3(a-d) compounds tested were found to have excelent antibacterial activities compare with 5(a-d) and 7(a-d) against Klebsiella pneumoniae and Escherichia coli. However, they were found to very good activities against Rhizoctonia solani and Fusarium oxysporum. 3(a-d) compounds tested were found to have very good antifungal activities compare with 5(a-d) and 7(a-d) against Rhizoctonia solani and Fusarium oxysporum.

\section{ACKNOWLEDGEMENTS}

The authors are grateful to the Jawaharlal Nehru Technological University Hyderabad for providing financial support.

\section{REFERENCES}

1. G. Jones, The Knovenagel Condensation Reaction in Organic Reactions, Wiley New York, Vol. 15, p. 204 (1967).

2. E. Knoevenagel, Ber, 31, 2585 (1898).

3. L.F. Tietze and U. Beifuss, In eds.: B.M. Trost, I. Fleming and C.H. Heathcock, Comprehensive Organic Synthesis, Pergamon: Oxford, Vol. 2, p. 341 (1991).

4. F. Freeman, Chem. Rev., 80, 329 (1980).

5. N. Zidar, T. Tomasic and R. Sink, J. Med. Chem., 53, 6584 (2010).

6. M. Ibrahim, A.M. Abdel-Hamed and M. El-Gohary, J. Braz. Chem. Soc., 22, 1130 (2011).

7. M. Oguchi, K. Wada and H. Honma, J. Med. Chem., 43, 3052 (2000).

8. M.S. Malamas, J. Sredy and J.I. Gunawan, J. Med. Chem., 43, 995 (2000).

9. R. Murugan, S. Anbazhagan and S.S. Narayanan, Eur. J. Med. Chem., 44, 3272 (2009).
10. U.V. Desai, D.M. Pore, R.B. Mane, S.B. Solabanavar and P.P. Wadgaonkar, Synth. Commun., 34, 25 (2004)

11. D. Fildes, V. Caignaert, D. Villemin and P. Jaffres, Green Chem., 3, 52 (2001).

12. F. Texier-Boullet and A. Foucod, Tetrahedron Lett., 23, 4927 (1982).

13. J.A. Cabello, J.M. Campelo, A. Garcia, D. Luna and J.M. Marians, J. Org. Chem., 49, 5195 (1984)

14. J.S. Yadav, B.V.S. Reddy, A.K. Basak, B. Visali, A.V. Narsaiah and K. Nagaiah, Eur. J. Med.Chem., 67, 546 (2004).

15. D.H. Yang, B.H. Yang, B.C. Chen and S.Y. Chen, Org. Prep. Proced. Int., 38, 81 (2006).

16. A.V. Narsaiah, A.K. Basak, B. Visali and K. Nagaiah, Synth. Commun., 34, 2893 (2004).

17. I. Rodriguez, S. Iborra, A. Corma, F. Rey and J.L. Jorda, Chem. Commun., 35, 593 (1999).

18. D. Prajapati, K.C. Lekhok, J.S. Sandhu and A.C. Ghosh, J. Chem. Soc. Perkin Trans. I, 9, 959 (1996).

19. P.S. Rao and R.V. Ratnam, Tetrahedron Lett., 32, 5821 (1991).

20. A.V. Narsaiah and K. Nagaiah, Synth. Commun., 33, 3819 (2003).

21. L. Martins, K.M. Vieira, L.M. Rios and D. Cardoso, Cat. Today, 133, 706 (2008).

22. U.P.N. Tran, K.K.A. Le and N.T.S. Phan, ACS Catal., 1, 120 (2011).

23. T.I. Reddy and R.S. Verma, Tetrahedron Lett., 38, 1721 (1997).

24. P. Formentin, H. Garcia and A. Leyva, J. Mol. Catal., 214, 137 (2004).

25. Y. Hu, Z.C. Chen, Z.C. Le and Q.G. Zheng, Synth. Commun., 34, 3801 (2004).

26. F. Santamarta, P. Verdia and E. Tojo, Catal. Commun., 9, 1779 (2008).

27. H. McNab, Chem. Soc. Rev., 7, 345 (1978).

28. G.A. Kraus and M.E. Krolski, J. Org. Chem., 51, 3347 (1986)

29. X. Huang and L. Xie, Synth. Commun., 16, 1701 (1986).

30. S. Nakamura, H. Rao and T. Ohwada, J. Org. Chem., 69, 4309 (2004).

31. M.T. Thorat, M.H. Jagdale, R.B. Mane, M.M. Salunkhe and P.P. Wadgaonkar, Curr. Sci., 56, 771 (1987).

32. P.S. Rao and R.V. Venkataratnam, Indian J. Chem., 32B, 484 (1993)

33. S. Miroslav, P. Daniel, A. Marta, F.Andres, C. Carmen, A. Fernando and A. Mercedes, J. Med. Chem., 52, 6217 (2009).

34. L.S.K. Tara and W.G. Gordon, Tetrahedron Lett., 42, 4783 (2001).

35. V. Ravichandran, R. Harish, K.S. Kumar and A.R. Kishore, Lett. Drug Design Discov., 8, 82 (2011).

36. Md. Kaspady, V.K. Narayanaswamy, M. Raju and G.K. Rao, Lett. Drug Design Discov., 6, 21 (2010).

37. S. Frankel, S. Reitman and A.C. Sonnenwirth, Gradwohl's Clinical Laboratory Methods and Diagnosis, Textbook on a Laboratory Procedure and their Interpretation, edn. 7, Vol. 2, p. 1406 (1970).

38. Ch. Navneet, K. Pawan, S. Chetan, R. Kamal, Aneja and K.S. Pawan, Lett. Drug Design Discov., 9, 63 (2012). 